\title{
Algoritma Adaptif Sistem Downlink menggunakan Recursive Least Square (RLS)
}

\author{
Agus Basukesti ${ }^{1}$, Bangga Dirgantara $\mathrm{A}^{2}$ \\ Program Studi Teknik Elektro ${ }^{1}$ \\ Program Studi Teknik Penerbangan ${ }^{2}$ \\ Sekolah Tinggi Teknologi Adisutjipto \\ J1. Janti, Blok R, Lanud Adisutjipto, Yogyakarta \\ Email : agus_basukesti@yahoo.com ${ }^{1}$, bangga_adiputra $a$ yahoo.com ${ }^{2}$
}

\begin{abstract}
GPS (Global Positioning System) is the popular system for navigation which assistance 32 satellites orbiting the earth. Currently, tracking positions using the Global Positioning System (GPS) is one of the best positioning tracking methods. However, GPS has a lot of noise, so filters are needed to handle with noise on GPS. In this research, the simulation is done to extract data from GPS sensors using RLS algorithm. From the results of identification and simulation, it can be concluded that the algorithm works well and need to analyze the advantages and disadvantages to be implemented on the downlink system designed. From the simulation results obtained that error estimation is convergent that is the longer the smaller.
\end{abstract}

Keywords : Adaptif, RLS, Error.

\begin{abstract}
ABSTRAK
GPS (Global Positioning System) adalah sebuah sistem yang paling sering digunakan untuk navigasi bantuan 32 satelit yang mengitari bumi. Penjejakan posisi dengan menggunakan Global Positioning System (GPS) merupakan salah satu metode penjejakan posisi yang terbaik saat ini.. Akan tetapi GPS memiliki banyak noise sehingga diperlukan filter untuk mengatasi noise pada GPS. Dalam penelitian ini dilakukan sebuah simulasi dalam mengekstrak data dari sensor GPS menggunakan algoritma RLS. Dari hasil identifikasi dan simulasi yang dilakukan dapat disimpulkan bahwa algoritma bekerja dengan baik dan perlu dianalisis kelebihan dan kekurangannya untuk diimplementasikan pada sistem downlink yang dirancang. Dari hasil simulasi didapatkan bahwa error estimasi sifat konvergen yaitu semakin lama semakin mengecil.
\end{abstract}

Kata kunci : Adaptif, RLS, Error.

\section{Pendahuluan}

Penjejakan posisi dengan menggunakan Global Positioning System (GPS) merupakan salah satu metode penjejakan posisi yang terbaik saat ini. GPS memberikan informasi posisi yang sering digunakan untuk navigasi pesawat tanpa awak. Pelaporan data posisi pesawat tanpa awak ke ground station penting dilakukan karena data tersebut akan digunakan untuk mengendalikan sistem downlink. Akan tetapi informasi dari GPS dapat mengalami ganguan karena sebuah noise. Dengan demikian algoritma estimasi posisi yang tahan terhadap noise penting untuk dikembangkan.

Pengembangan Sistem downlink data adaptif pada pesawat tanpa awak perlu dikembangkan untuk meningkatkan daya jelajah pesawat tanpa awak. Sistem downlink yang 
dapat mengestimasi posisi dengan akurat dan tahan terhadap noise merupakan tujuan utama yang ingin dicapai dalam penelitian ini. Penelitian untuk mengani noise pada GPS telah dilakukan sebelumya (Chaffee dan Abel,1992 - Zahaby, Gaonjur dan Farajian, 2009). Dalam penelitian ini dirancang sebuah algoritma estimasi posisi dengan menggunakan metode Recursive Least Square (RLS).

\section{Metode}

Langkah pertama dalam mendesain algoritma RLS adalah dengan mendesain persamaan model yang digunakan. Dalam penelitian ini data yang akan digunakan adalah data posisi. Data yang digunakan dinyatakan dalam persamaan 1 .

$$
\begin{array}{ll}
\mathrm{x} & =\mathrm{Lat}_{\text {uav }}-\text { lat }_{\text {ground }} \\
\mathrm{y} & =\text { Long }_{\text {uav }}-\text { Long ground }_{\text {I }} \\
\mathrm{z} & =\mathrm{Alt}_{\text {uav }}-\mathrm{Alt}_{\text {ground }}
\end{array}
$$

$U A V$ adalah posisi dari pesawat tanpa awak.

ground adalah posisi dari sistem downlink.

RLS merupakan algoritma adaptif dengan menggunakan prosses koreksi hasil sebelumnya. Koreksi dilakukan dengan menentukan nilai gain estimasi $(\mathbf{G ~} \mathbf{k})$ dan error kovarian $(\mathrm{P} \mathbf{k})$ dari model yang digunakan. Langkah algoritma RLS dinyatakan pada persamaan 2.

$$
\begin{aligned}
& \mathrm{G} k=\frac{P(k-1)}{1+\varphi^{\mathrm{T}}(\mathrm{k}) \mathrm{P}(\mathrm{k}-1) \varphi(\mathrm{k})} \\
& \theta \mathrm{k}=\theta(\mathrm{k}-1)+\mathrm{G}(\mathrm{k})\left[\mathrm{z}(\mathrm{k})-\varphi^{\mathrm{T}}(\mathrm{k}) \theta(\mathrm{k}\right. \\
& \mathrm{Pk}=\mathrm{P}(\mathrm{k}-1)-\mathrm{G}(\mathrm{k}) \varphi^{\mathrm{T}}(\mathrm{k}) \mathrm{P}(\mathrm{k}-1)
\end{aligned}
$$

Identifikasi sistem diperlukan untuk mengimplementasikan algoritma pada alat yang dirancang. Data sensor secara umum dapat dinyatakan pada persamaan 3.

$$
\begin{aligned}
& z_{x}=x+w \\
& z_{y}=y+w \\
& z_{z}=z+w
\end{aligned}
$$

$\boldsymbol{z}_{\boldsymbol{x}}, \boldsymbol{z}_{\boldsymbol{y}}$ dan $\boldsymbol{z}_{\boldsymbol{z}}$ adalah nilai $\boldsymbol{x}, \boldsymbol{y}$ dan $\boldsymbol{z}$ yang terbaca oleh sensor dengan $\boldsymbol{w}$ adalah noise sensor. Dengan data pada persamaan 3 , regressor sistem dinyatakan dengan $\theta(k)$. Sedangkan parameter $\varphi(k)$ selalu bernilai 1 . Error kovarian dinyatakan dengan $P(k)$. Inisialisasi yang digunakan dalam algoritma ini adalah

$$
\begin{aligned}
& \theta 0=0 \\
& \text { P } 0=0,1 .
\end{aligned}
$$

\section{Hasil dan Pembahasan}

Algoritma yang telah dirancang diujikan pada sebuah model data yang mengandung noise. Hasil simulasi algoritma pada model data ditunjukkan pada Gambar 1. Gambar 1 menunjukkan bahwa algoritma RLS dapat mengestimasi data real meskipun data sensor memiliki noise. Analisis error algoritma dalam mengestimasi pada Gambar 2 menunjukkan 
bahwa error estimasi pada algoritma yang dirancang memiliki nilai yang cenderung mengecil (konvergen) pada 25 detik awal. Setelah melewati 25 detik awal, hasil estimasi memiliki nilai yang relativ dekat dengan nilai sesungguhnya dengan nilai error lebih kecil daripada estimasi posisi secara langsung menggunakan data sensor. Estimasi menggunakan RLS memerlukan waktu untuk mencapai error minimal. Algoritma RLS juga sangat dipengaruhi oleh penentuan nilai awal estimasi sebagaimana terlihat pada Gambar 3. Meskipun error dapat mengecil dengan sendirinya, Algoritma tersebut memerlukan waktu untuk mendapatkan error terkecil tergantung seberapa dekat nilai estimasi awal dengan nilai sesungguhnya.

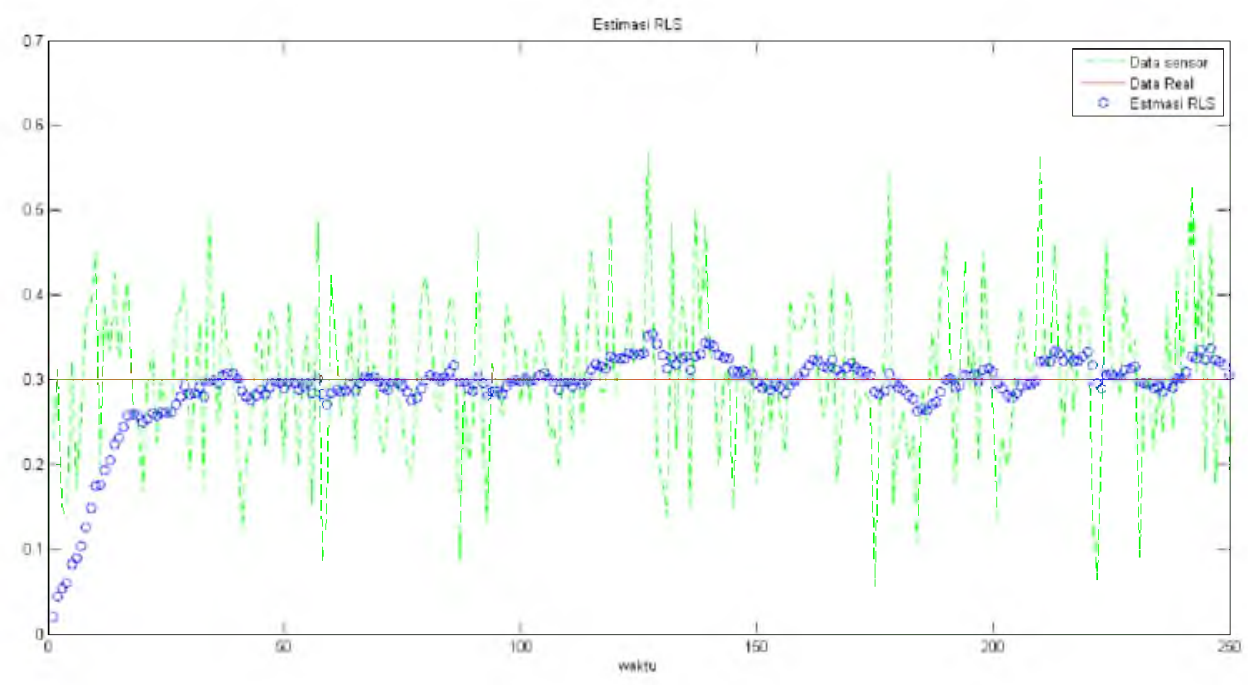

Gambar 1. Hasil Simulasi

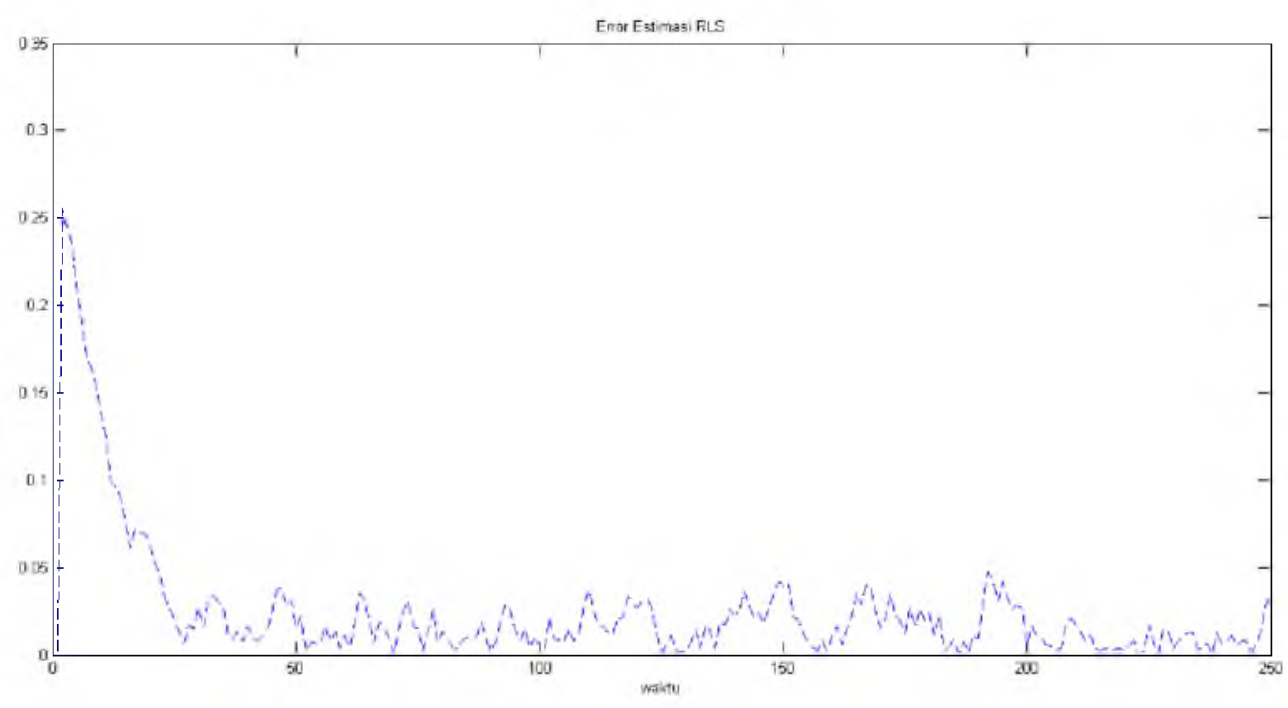

Gambar 2. Error Estimasi RLS 


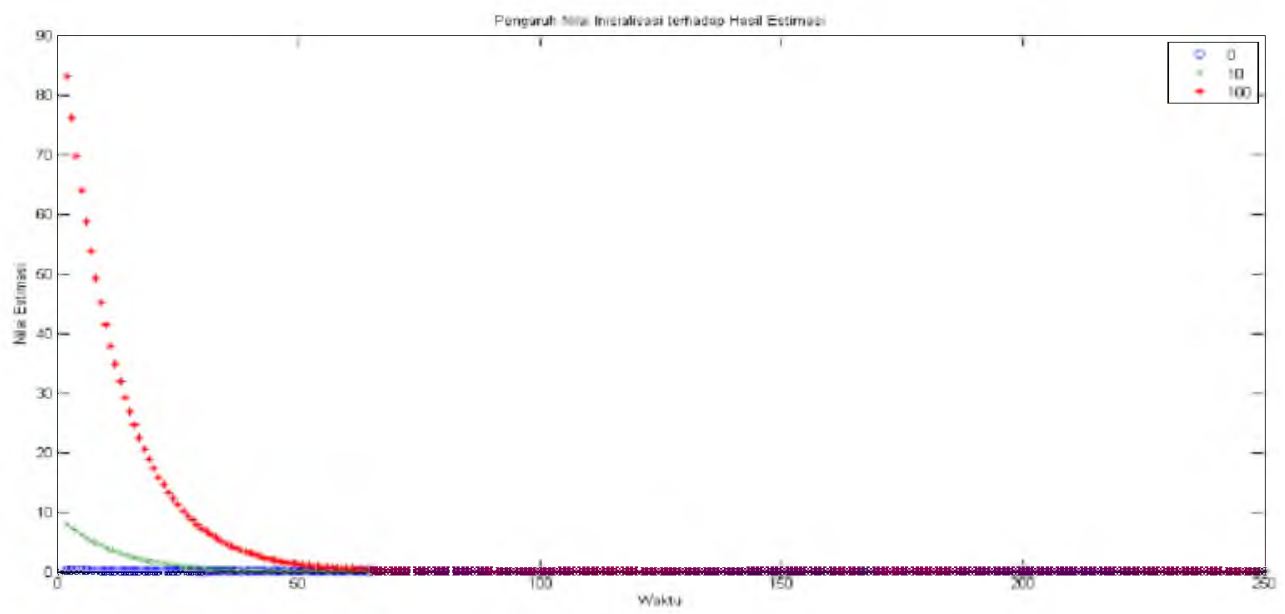

Gambar 3. Pengaruh Nilai inisialisasi pada Estimasi RLS

Dari Simulasi yang dilakukan dapat disimpulkan bahwa algoritma RLS dapat digunakan untuk mengestimasi posisi dengan baik. Akan tetapi ketepatan menentukan nilai awal menjadi tantangan tersendiri karena penentuan nilai awal akan mempengaruhi respon transien dalam mengestimasi posisi.

\section{Kesimpulan}

Dari hasil simulasi yang dilakukan dapat disimpulkan bahwa algoritma adaptıf yang dirancang dapat bekerja dengan baik dan perlu dianalisis kelebihan dan kekurangannya untuk diimplementasikan pada sistem downlink yang dirancang. Dari hasil simulasi didapatkan bahwa error estimasi sifat konvergen yaitu semakin lama semakin mengecil.

\section{Daftar Pustaka.}

J. W. Chaffee and J. S. Abel, "The GPS filtering problem," Position Location and Navigation Symposium, 1992. Record. 500 Years After Columbus - Navigation Challenges of Tomorrow. IEEE PLANS '92., IEEE. pp. 12-20, 1992.

C. Hide, T. Moore, and M. Smith, "Adaptive Kalman filtering algorithms for integrating GPS and low cost INS," Position Location and Navigation Symposium, 2004. PLANS 2004. pp. 227-233, 2004.

X. Mao, M. Wada, and H. Hashimoto, "Nonlinear filtering algorithms for GPS using pseudorange and Doppler shift measurements," Intelligent Transportation Systems, 2002. Proceedings. The IEEE 5th International Conference on. pp. 914-919, 2002. 
I. M. Taylor and M. A. Labrador, "Improving the energy consumption in mobile phones by filtering noisy GPS fixes with modified Kalman filters," Wireless Communications and Networking Conference (WCNC), 2011 IEEE. pp. 2006-2011, 2011.

L. Wu, H. Ma, W. Ding, Q. Hu, G. Zhang, and D. Lu, "Study of GPS Data De-Noising Method Based on Wavelet and Kalman Filtering," Circuits, Communications and System (PACCS), 2011 Third Pacific-Asia Conference on. pp. 1-3, 2011.

S. Yamaguchi and T. Tanaka, "GPS Standard Positioning using Kalman filter," SICE-ICASE, 2006. International Joint Conference. pp. 1351-1354, 2006.

M. Zahaby, P. Gaonjur, and S. Farajian, "Location tracking in GPS using Kalman Filter through SMS," EUROCON 2009, EUROCON '09. IEEE. pp. 1707-1711, 2009. 
Agus Basukesti, Bangga Dirgantara A. 